\title{
Project Based Learning: An Innovative Approach for Integrating 21st Century Skills
}

\author{
Rajendra Pawar ${ }^{1}$, Sushma Kulkarni', Sachin Patil ${ }^{3}$ \\ ${ }^{1}$ Assistant Professor, Department of Mechanical Engineering, \\ ${ }^{2}$ Professor, Department of Civil Engineering, \\ ${ }^{3}$ Associate Professor, Department of Mechanical Engineering, \\ K. E. Society's Rajarambapu Institute of Technology, Rajaramnagar. Affiliated to Shivaji University Kolhapur, Maharashtra, India \\ rajendra.pawar@ritindia.edu \\ 2sushama.kulkarni@ritindia.edu \\ ssachink.patil@ritindia.edu
}

\begin{abstract}
Project Based Learning (PBL) is an instructional technique constructed upon learning activities and real problems that have brought challenges for students to solve. The PBL is an innovative approach to teaching and learning that teaches students not just content, but also important skills for success in the 21 st century. The attempt has been made to integrate the 21 st-century skills through PBL implemented to the course Kinematics of Machines. The PBL allows students to work on their own ideas/concepts and make decisions that affect project outcomes and the learning process. The main objective of PBL is to develop high quality and the authentic mechanism that fulfills the desired need. The research focused on developing 21st-century skills of Mechanical Engineering students in the second year of Engineering through PBL activity. The data was collected through observations, evolution rubrics, and student feedback. The results showed that students have developed their creativity, communication and presentation, time management, self-assessment, group participation, leadership, and critical thinking skills. PBL approach focuses on realworld problems and challenges using problemsolving, investigation and decision-making skills. The intention of this study is to investigate the effect of PBL on student's skills and learning outcomes.
\end{abstract}

\section{Rajendra Pawar}

Assistant Professor, Department of Mechanical Engineering, K. E. Society's Rajarambapu Institute of Technology, Rajaramnagar. Affiliated to Shivaji University Kolhapur, Maharashtra, India rajendra.pawar@ritindia.edu
Keywords: Project-based learning, 21st Century skills, Mechanism, Teaching, Learning

\section{Introduction}

In the emerging world of technology, industry, and society depend on engineers for the innovative products that meet customer need and are safe, efficient, reliable, and competitive in the global market. The engineering institutes and universities produce technically competent graduates who understand engineering concepts and demonstrate the ability to apply them in the real world; they often lack the people skills that enable them to meet their full potential. The 21 st-century engineer needs to be not only technically competent but also creative and able to work well in teams, communicate effectively, and create innovative products that fulfill customer needs (Kokotsaki 2016). The research confirms that to be successful in today's rapidly changing and complex world, students need to develop a broader set of knowledge and skills beyond academics. The PBL approach is one of the best to develop the basic concepts, engineering skills required for problemsolving and project development. The PBL is a student-driven approach for learning, that motivates the students towards the construction of knowledge and skills that are new to them (Tiwari 2017). The main challenge observed in the teaching-learning process is the fundamental concepts need to be developed, meanwhile, 21 st-century skills are also important to be developed (Hadinugrahaningsih 2017). 
The PBL was introduced to second-year students of the Mechanical engineering department under the kinematics of machine course. The course deals with the study and analysis of the motion of mechanisms. The design of any machine starts with the selection and design of the mechanism that will fulfill the desired motion. The systematic innovative approach has been used to teach kinematics of machine course through PBL activities. Through PBL activity students have learned the concepts of mechanism and developed the skills required for the 21 st century by doing the projects in groups (Bell 2010). PBL is normally done by groups of students working together toward a common goal. The major myth of student engagement in PBL is that all learning should be enjoyable (Chanpet et al 2018). The research showed that the application of project-based teaching improves the quality of teaching and learning (Jolanta 2015).

\section{Methodology}

The PBL activity was carried out in the Department of mechanical engineering for secondyear students in a 4th semester. The study consists of a class of 76 students for the PBL activity. The whole division was divided into 17 groups, each group had 4 -5 students. The PBL activity was systematically planned for the entire semester in parallel with the classroom delivery. At the beginning of the semester, the students were oriented regarding the PBL activity, PBL plan, outcomes and evaluation rubrics for the entire semester. Teaching in a PBL approach requires the right amount of guidance at the right time toward learning outcomes. The PBL activity was conducted for the following outcomes,

At the end of this activity, students are able to

1. Select a suitable mechanism for a given application.

2. Design and analyze the mechanism for motion, velocity, and acceleration.

3. Develop the prototype as per the design in a given constraint.

4. Collaborates with team members, take responsibilities and develop decision-making skills.

\section{Present and communicate effectively}

PBL activity was divided into four major phases; problem identification, selection of best mechanism, Design and development using optimum resources and the creation of video of the final developed mechanism. The theory and PBL classes were well synchronised and each theory session were designed with activity based teaching learning approach. The mechanism kits were developed and demonstration models of mechanism were purchased for the PBL classes shown in Fig. 1. For the evaluation of the individual student, rubrics were developed and each stage was evaluated. Initially, students were asked to identify the problems related to motion transmission in different applications and gather the data related to that. After that students have generated three to four solutions and selected the best solution by the process of analysis.

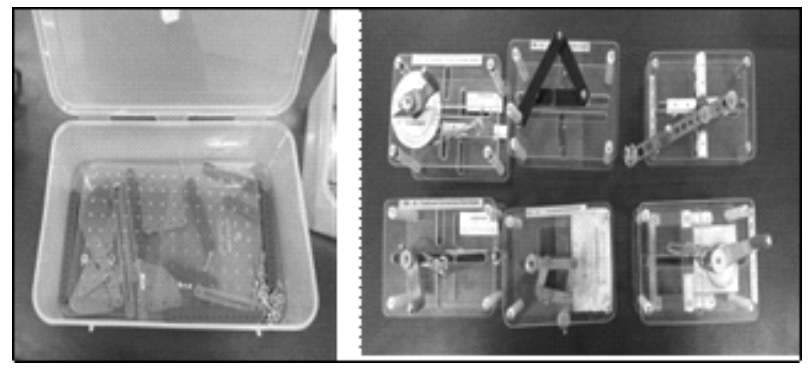

Fig. 1 : Mechanism kit and Demonstration models

The students have used different software like MechAnalyzer, linkages, etc. for the design and analysis of mechanisms, which are available online shown in Fig. 2. After the design stage, mid-review presentations were carried out to check the status and feasibility of each project. Each group presented their problem with the best solution and the final design of the mechanism. For the development of the mechanism, the MAKIT kit and project lab were available for the student. At the end of the activity, students were asked to fill the feedback on a ten-point scale and also asked for suggestions to improve.

The PBL activity implemented for the Kinematics of machine course was systematically planned for the

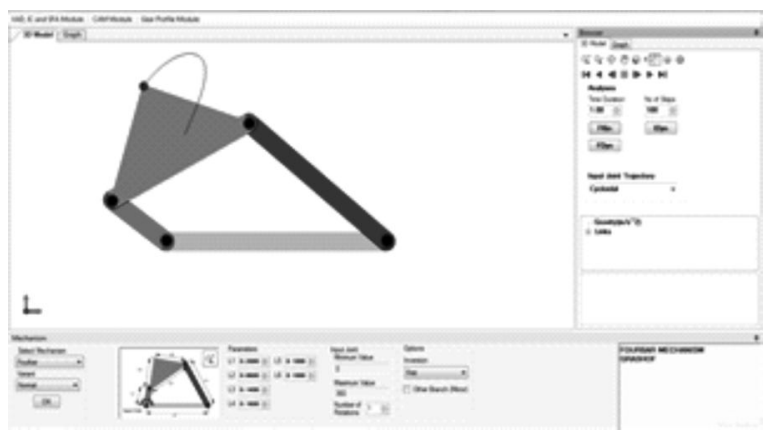

Fig. 2: Mechanism Analysis using Mechanalyser software 
entire semester. The detailed plan for the PBL is displayed in Table 1; the activities are planned in parallel with classroom delivery. Each session of classroom delivery is planned with an activity-based learning approach so that it will benefit the student for their project development and learning will be enjoyable.

Table 1. PBL plan for the semester

\begin{tabular}{|l|l|}
\hline \multicolumn{1}{|c|}{ Activity } & \multicolumn{1}{c|}{ Duration } \\
\hline Orientation on PBL & $1^{\text {st }}$ Week of Jan. \\
\hline $\begin{array}{l}\text { Project Group Formation } \\
(4-5 \text { students in each Group })\end{array}$ & $1^{\text {st }}$ Week of Jan. \\
\hline $\begin{array}{l}\text { Problem identification and } \\
\text { Submission of a problem } \\
\text { statement }\end{array}$ & $2^{\text {nd }}-4^{\text {th }}$ week of Jan. \\
\hline Mechanism Selection & $1^{\text {st }}-2^{\text {nd }}$ week of Feb. \\
\hline $\begin{array}{l}\text { Design and Analysis of } \\
\text { Mechanism }\end{array}$ & $3^{\text {rd }}-4^{\text {th }}$ week of Feb. \\
\hline Project Design Review & $1^{\text {st }}$ week of March \\
\hline Model Development & $1^{\text {st }}-3^{\text {rd }}$ week of March \\
\hline Final working model with Video & $4^{\text {th }}$ week of March \\
\hline Report submission & $1^{\text {st }}$ week of April \\
\hline
\end{tabular}

In order to select the proper mechanism for the specific application and to solve the mechanical problem, the group discussion/brainstorming is carried out in the classroom. In a group, students have identified/generated three to four solutions and selected the best solution by applying different criteria. At the end of the group discussion, students have presented their best solution in front of all for the validation. The group discussion and presentation of the best design solution is shown in Fig. 3 and Fig. 4 respectively.

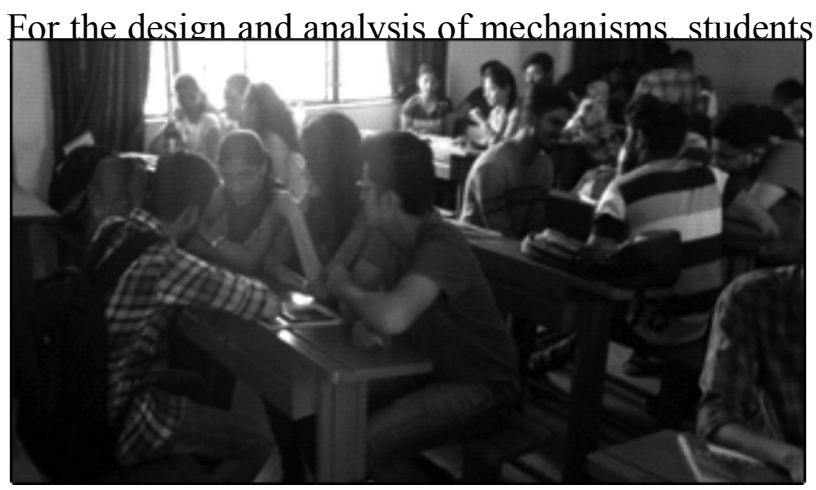

Fig. 3: Group Discussion

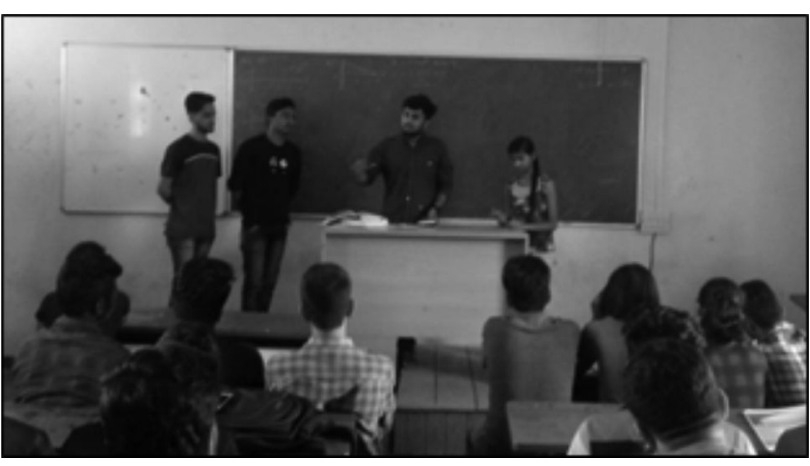

Fig. 4 : Presentation of the best design solution

have used different software's available online, where motion, velocity, and acceleration of different links and joints are analyzed. After completion of the final design of the mechanism, students have developed their mechanisms using the MAKIT kit, which was purchased under the Kinematics of machine Lab. specifically for this activity. In addition to that, the Project Lab. was available for the student for the development. For effective utilization of laboratory facilities for 75 students, the class divided into 4 batches, each batch containing 4 - 5 project groups and time slots were allotted to each batch for laboratory work. Fig. 5 shows the development of a mechanism by the student using MAKIT.

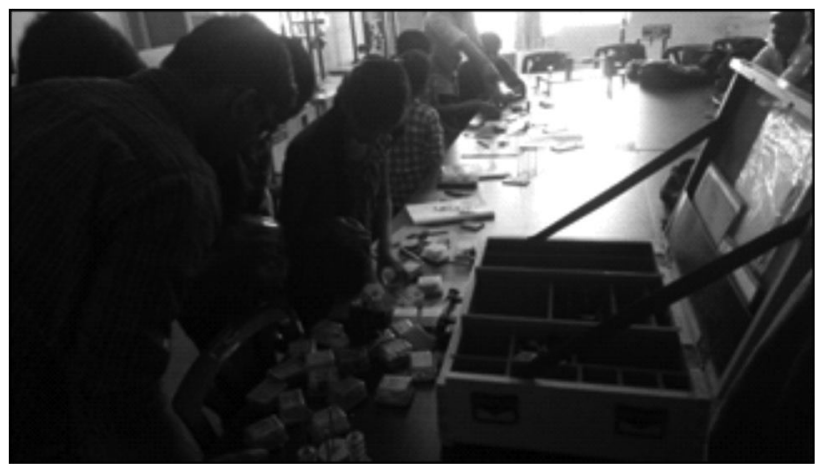

Fig. 5 : Mechanism development with MAKIT

The teacher's role in PBL is one of facilitator, advisor, guide, mentor, coach; not directing and managing all student work. The PBL activity was evaluated using evaluation rubrics on a scale of $0-5$ as shown in Table 2.

Table 2 . PBL Evolution Rubrics

\begin{tabular}{|l|l|l|l|}
\hline Criterion & Excellent (5-4) & Good (3-2) & Poor (0-1) \\
\hline $\begin{array}{l}\text { Selection of } \\
\text { Mechanism }\end{array}$ & $\begin{array}{l}\text { Optimum } \\
\text { selection of } \\
\text { mechanism } \\
\text { fulfills the } \\
\text { requirement }\end{array}$ & $\begin{array}{l}\text { Good } \\
\text { Selection of } \\
\text { Mechanism }\end{array}$ & $\begin{array}{l}\text { Poor } \\
\text { selection of } \\
\text { the } \\
\text { mechanism }\end{array}$ \\
\hline
\end{tabular}




\begin{tabular}{|c|c|c|c|}
\hline $\begin{array}{l}\text { Design and } \\
\text { Analysis of } \\
\text { Mechanism }\end{array}$ & $\begin{array}{l}\text { Excellent } \\
\text { design; a clear } \\
\text { description of } \\
\text { methods and } \\
\text { analysis }\end{array}$ & $\begin{array}{l}\text { Good } \\
\text { design but } \\
\text { methods } \\
\text { unclear }\end{array}$ & $\begin{array}{l}\text { Not included } \\
\text { or } \\
\text { significantly } \\
\text { incomplete }\end{array}$ \\
\hline $\begin{array}{l}\text { Prototype } \\
\text { Development }\end{array}$ & $\begin{array}{l}\text { Excellent } \\
\text { development of } \\
\text { mechanism as } \\
\text { per design }\end{array}$ & $\begin{array}{l}\text { Good } \\
\text { development } \\
\text { of } \\
\text { mechanism } \\
\text { with less } \\
\text { accuracy }\end{array}$ & $\begin{array}{l}\text { Poor } \\
\text { development } \\
\text { of mechanism }\end{array}$ \\
\hline $\begin{array}{l}\text { Group Work } \\
\text { and } \\
\text { leadership }\end{array}$ & $\begin{array}{l}\text { Takes } \\
\text { Initiatives } \\
\text { coordinates as } \\
\text { a team leader }\end{array}$ & $\begin{array}{l}\text { Works with } \\
\text { proper } \\
\text { coordination } \\
\text { among team } \\
\text { member }\end{array}$ & $\begin{array}{l}\text { Works } \\
\text { individually } \\
\text { without } \\
\text { coordination }\end{array}$ \\
\hline $\begin{array}{l}\text { Demonstratio } \\
\mathrm{n} \text { and } \\
\text { Presentation } \\
\text { Skill }\end{array}$ & $\begin{array}{l}\text { Excellent } \\
\text { organization \& } \\
\text { presentation }\end{array}$ & $\begin{array}{l}\text { Good } \\
\text { organization } \\
\& \\
\text { presentation }\end{array}$ & $\begin{array}{l}\text { Basic } \\
\text { organization } \\
\text { and } \\
\text { presentation }\end{array}$ \\
\hline
\end{tabular}

Table 3. Project titles with YouTube video link

\section{Result and Discussion}

Project-based teaching and learning seem to be one of the most effective tools. From overall observations and student's feedback, it is found that PBL was considered to be worthwhile and enhances student's skills including creativity, communication, teamwork, and self-directed study skills. Through PBL activity 15 new mechanisms were developed by the students for different applications. Students gave their strong consent for the continuation of PBL in the subsequent semester. Students have prepared the videos of mechanism with an explanation of construction and working and uploaded those videos on Youtube. The list of project titles along with the YouTube link is shown in Table 3. Most of the videos uploaded on Youtube have received more than 800 views in one week.

In PBL teacher plays a significant role in helping students in the activity by shaping the opportunity for learning, thinking, planning and guiding students. PBL requires sustained framework and mentorship over a significant period of time. One can't disengage from the process of PBL as easily as he/she can walk out of a classroom when the class is over (Ibrahim et al. 2015). Fig. 6 and 7 show the sample mechanisms developed by the students.

It is observed that, students develop 21st - century skills through PBL that will encourage them in becoming creative members of society. Many 21st century skills cannot assessable with rubrics, so it needs to shift the assessment technique. Student

\begin{tabular}{|c|c|c|}
\hline $\begin{array}{l}\text { Sr. } \\
\text { No. }\end{array}$ & Project Title & YouTube Video Link \\
\hline 1 & $\begin{array}{l}\text { Lemon squeezer } \\
\text { mechanism }\end{array}$ & https://youtu.be/IG8YDtQCcCk \\
\hline 2 & $\begin{array}{l}\text { Automatic sawing } \\
\text { machine }\end{array}$ & https://youtu.be/CNs0r7AXVA4 \\
\hline 3 & $\begin{array}{l}\text { Automatic shaping } \\
\text { machine }\end{array}$ & https://youtu.be/acter $2 \mathrm{cFaIU}$ \\
\hline 4 & $\begin{array}{l}\text { Box transport } \\
\text { mechanism }\end{array}$ & https://youtu.be/FhX CJEaW64 \\
\hline 5 & $\begin{array}{l}\text { Automatics Siever } \\
\text { mechanism }\end{array}$ & https://youtu.be/8WxT9wEfF8E \\
\hline 6 & $\begin{array}{l}\text { Gear shifter } \\
\text { mechanism }\end{array}$ & https://youtu.be/NXrTfz6hRUI \\
\hline 7 & $\begin{array}{l}\text { Quick return shaper } \\
\text { mechanism }\end{array}$ & https://youtu.be/VSnwK -E3nSg \\
\hline 8 & $\begin{array}{l}\text { Clothes Squeezing } \\
\text { Mechanism }\end{array}$ & https://youtu.be/f -PfDsuM1PE \\
\hline 9 & $\begin{array}{l}\text { Elevating } \\
\text { mechanism }\end{array}$ & $\frac{\text { https://youtu.be/Np4AHsPxRW }}{\underline{M}}$ \\
\hline 10 & $\begin{array}{l}\text { Slicer with a } \\
\text { feeding mechanism }\end{array}$ & https://youtu.be/zklpSNuTRDY \\
\hline 11 & $\begin{array}{l}\text { Shutter and } \\
\text { windows opening } \\
\text { mechanism }\end{array}$ & https://youtu.be/eatvBj70k0c \\
\hline 12 & $\begin{array}{l}\text { Punching } \\
\text { Mechanism }\end{array}$ & https://youtu.be/ nEv7qDigzM \\
\hline 13 & $\begin{array}{l}\text { Copy lathe } \\
\text { attachment }\end{array}$ & $\begin{array}{l}\text { Videos } \backslash \text { Copy lathe } \\
\text { machine.mp4 }\end{array}$ \\
\hline 14 & $\begin{array}{l}\text { Chakli Making } \\
\text { Machine }\end{array}$ & $\begin{array}{l}\text { Videos } \backslash \text { Chakli Making } \\
\text { Machanism.mp4 }\end{array}$ \\
\hline 15 & Lifting Mechanism & $\underline{\text { Videos } \backslash \text { Lifting mechanism.mp4 }}$ \\
\hline
\end{tabular}

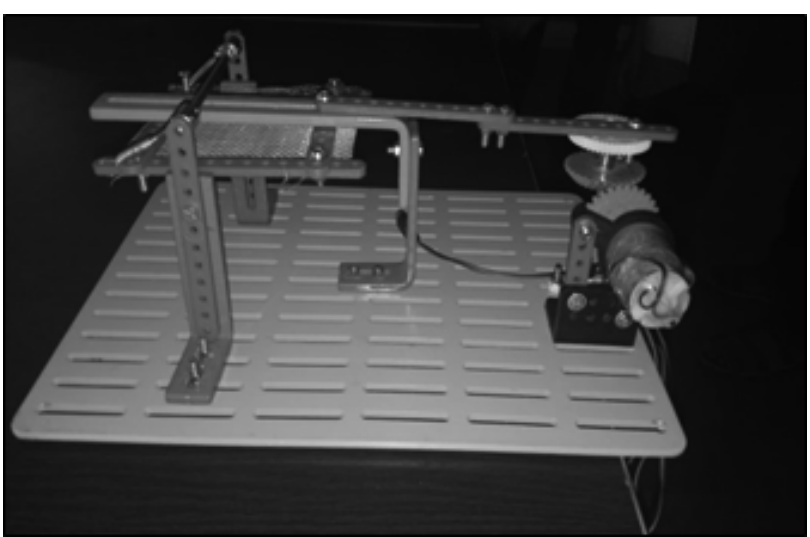

Fig. 6 : Automatics Siever mechanism 


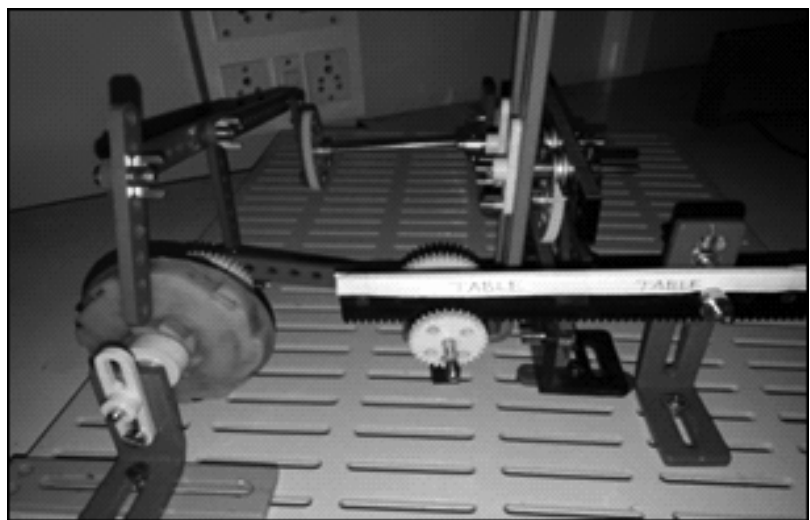

Fig. 7 : Automatic shaping machine

reflects on how well they worked in a collaborative group and how well they contributed, discussed, listened, and welcomed other group members' ideas. Students also self-evaluate their own projects, interests, motivations, efforts, and productivity levels. Students become critical friends by giving constructive feedback to each other, which helps them become aware of their own strengths and improve on their collaborations with each other. The best mechanism competition was also arranged to motivate the students, where the student has to vote for the best project except his/her won mechanism. The student feedback and voting for the best project were taken by using a Google sheet. The lemon squeezer mechanism was at number one position with

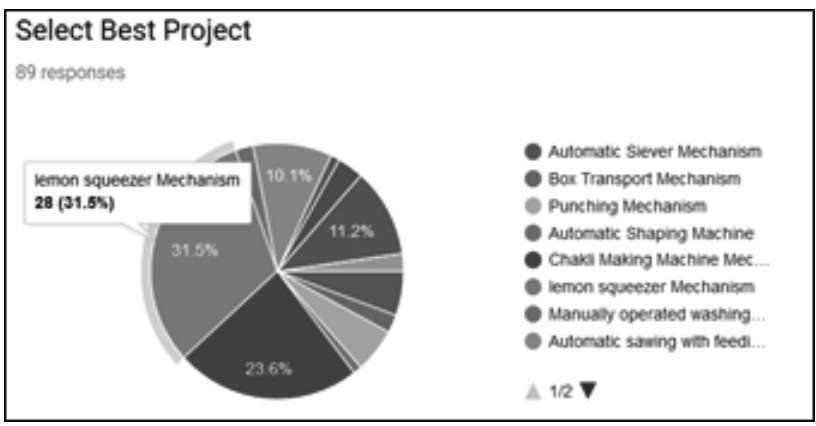

Fig. 8 : Student voting for the best project

All students have taken a very good interest in PBL and $67 \%$ of student rated this activity 10 out of 10 shown in Fig. 9. The sample questions for student's feedback are listed below.

1. What is the most important skill you learned during the PBL activity?

2. What is the most challenging part of the project?

3. What was the most enjoyable part of this PBL activity?
4. How could your teacher improve PBL activity to make it better next time?

5. How much you will rate the PBL activity? 28 votes out of 89 responses (31.5\%) shown in Fig. 8.

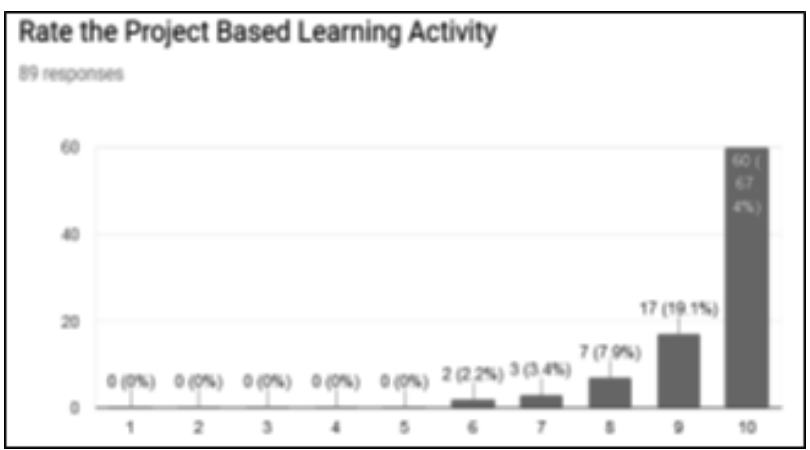

Fig. 9 : Student response for PBL activity

The attainment of outcomes is calculated with the help of evaluation rubrics shown in Table 2. Each student's work was evaluated using a rubric sheet and mapped with outcomes to obtain attainment. The commercial software Ioncudos is used for the calculation of course outcome attainment. The details of evaluation rubrics, course outcomes, mapping, and student's marks etc. were provided as input parameters to Ioncudos software for the calculation of attainment. The average based method is utilised for the calculation of attainment. The attainment obtained from PBL activity is shown in Fig. 10. From the attainment, it is observed that students are still lacking in communication and presentation skills. The basic concepts and technical skills are observed at an aboveexpected level.

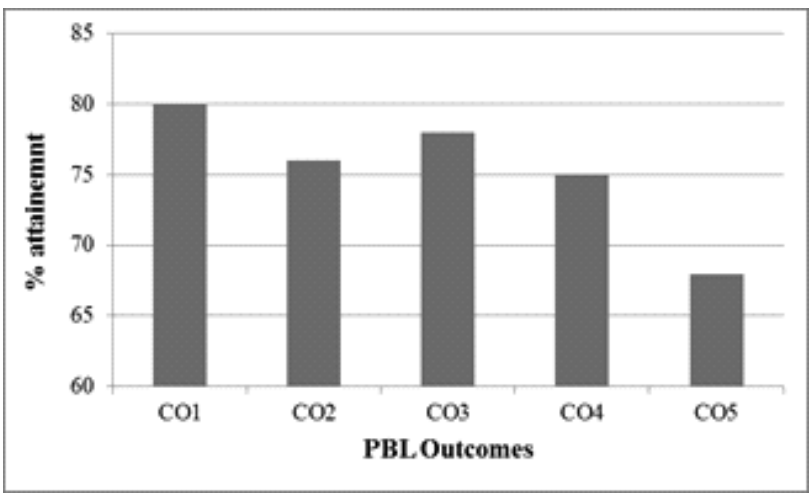

Fig. 10 : Attainment of PBL outcomes

Following observations were made through the PBL activity;

- Students gathered and compare information from 
different sources (online, field) for the completion of the task. Students designed their own mechanism and draw conclusions based on analysis and appropriate information.

- Students tried to solve complex problems or answer questions that have no single correct solution

- Students also gave suggestions and feedback to peers or assess other students' work

- Students convey their ideas using media other than a written paper (such as posters or videos). Students also presented their ideas in front of others and also answered questions in front of an audience.

- Students divided the task in the group as per the student's capabilities to complete the project in the given time.

- Planning of activities in PBL is the key point for the success of PBL.

- Role of faculty is very important and need to put more time and efforts at first time.

- The special classroom and laboratory facilities are required for the PBL.

- Also skilled laboratory assistant is required to provide the laboratory facilities.

- Students were intensely participated in the PBL activities and shown great enthusiasm, excitement and self-motivation during activities.

\section{Conclusion}

The attempt has been made to direct teachinglearning towards the more authentic and studentcentered approach. PBL allows students to reflect upon their own ideas and opinions, and make decisions that affect project outcomes and the learning process. PBL helped in increasing student's confidence level and updated knowledge on the concerned topic with an enhancement of communication, data collection, analytical and presentation skills. It has also given a preview on group dynamics and team building while working in small groups. For the successful implementation of the PBL for the KOM course; the planning, laboratory facilities, activity based teaching are the key aspects. The faculty advisor needs to give more time and attention for the PBL activity after working hours too. The role of student, laboratory assistant and teaching assistant are the important facet for the success of the PBL activity. The student involvement during the class activities and project activities were excellent and achieved technical as well as soft skills required for 21 st century.

\section{References}

[1] Bell S., (2010) Project-based learning for the 21st century; Skills for the future, Clearing House, 83(2), 39-43.

[2] Chanpet Punyapat, Komkrit Chomsuwan, Elizabeth Murphy, (2018) Online Project-Based Learning and Formative Assessment, Technology, Knowledge and Learning, 1-21.

[3] Hadinugrahaningsih Tritiyatma, Yuli Rahmawati, and Achmad Ridwan (2017) Developing 21stcentury skills in chemistry classrooms: Opportunities and challenges of STEAM integration, 1868, 030008, 1-8.

[4] Ibrahim Bilgin, Yunus Karakuyu, Yusuf AY, (2015) The Effects of Project Based Learning on Undergraduate Students' Achievement and SelfEfficacy Beliefs Towards Science Teaching, Eurasia Journal of Mathematics, Science and Technology Education 11(3), 469-477.

[5] Jolanta Lasauskiene, Asta Rauduvaite (2015) Project-Based Learning at University: Teaching Experiences of Lecturers, Procedia - Social and Behavioral Sciences, Volume 197,788-792

[6] Kokotsaki, D. Menzies, V. and Wiggins A. (2016) Project-based learning: A review of the literature, Improving Schools, 19(2), 267-277.

[7] Tiwari Ranjana, Raj Kumar Arya, Manoj Bansal, (2017) Motivating Students for Project-based Learning for Application of Research Methodology Skills, International Journal of Applied and Basic Medical Research, 7(Suppl 1), S4-S7. 